\title{
Heroes in the Bedroom? Iconoclash and the Search for Exemplarity in India
}

\section{Malvika Maheshwari}

\section{OpenEdition}

\section{Journals}

\section{Electronic version}

URL: http://journals.openedition.org/samaj/3044

DOI: $10.4000 /$ samaj.3044

ISSN: $1960-6060$

\section{Publisher}

Association pour la recherche sur l'Asie du Sud (ARAS)

Printed version

ISBN: 1960-6060

\section{Electronic reference}

Malvika Maheshwari, «Heroes in the Bedroom? Iconoclash and the Search for Exemplarity in India »,

South Asia Multidisciplinary Academic Journal [Online], 4 | 2010, Online since 17 December 2010, connection on 30 April 2019. URL : http://journals.openedition.org/samaj/3044 ; DOI : 10.4000/ samaj.3044

This text was automatically generated on 30 April 2019

\section{(c) $(1) \odot$}

This work is licensed under a Creative Commons Attribution-NonCommercial-NoDerivatives 4.0 International License. 


\title{
Heroes in the Bedroom? Iconoclash and the Search for Exemplarity in India
}

\author{
Malvika Maheshwari
}

1 The increasing influence of religion in politics and the socio-political strengthening of religious nationalism since the 1990s in India have, among other things, impacted art practice in unprecedented ways. Artists and works of art were dragged into controversies and suffered violent attacks targeting the religious identity of the artists, their depiction of gods and goddesses or their representation of women; in some cases, these attacks addressed more political concerns, and were conceived as an embarrassment to the ruling government. Among the participants in these attacks on the nation's visual and artistic fabric were secularists, Hindu nationalists, more marginally Muslim fundamentalists and Christian revivalists, each trying to infuse their peculiar characteristic acrimony into the narrative. Such interventions have had momentous violent consequences, each faction aiming at nothing short of capturing the nation's political pedestal and a cultural revamp with the chance of shaping India's identity and destiny in the coming decades.

2 The straining of relations between religious communities concomitant with the decline of secularism as a practice, if not as a norm, since the 1990s, provides the background to position the attacks on artists. However, understanding the attacks solely based on these inferences, though demonstrable, may not be adequate, for it overlooks the most important agent in these episodes of iconoclasm: the individuals who lead the attacks and indulge in violence. Furthermore, by incriminating politico-religious entrepreneurs only, one fails to acknowledge the prerequisite of an audience or viewership in such acts of violence. 'Iconoclash' itself is a staged spectacle, which, paradoxically, gives greater visibility to the images under attack, while transforming the attackers into performers. Through media attention to such acts of vandalism, attackers gain social acknowledgment or face opposition, which perhaps they otherwise would not have, at least not in such proportions (Rajagopal 2001). Critical factors in the escalation and social representations of these attacks can be found in the behavior of the attackers themselves, 
and more tentatively in the 'motivations' of these attackers, or at least in the justifications they give for such actions. As we will see, these justifications are complex and often contradictory. As such, they introduce an element of uncertainty in these episodes of 'iconoclash'. Following Bruno Latour, I distinguish 'iconoclash' from 'iconoclasm':

Iconoclasm is when we know what is happening in the act of breaking and what the motivations for what appears as a clear project of destruction are; iconoclash, on the other hand, is when one does not know, one hesitates, one is troubled by an action for which there is no way to know, without further enquiry, whether it is destructive or constructive (Latour 2002: 14).

In this article, I turn attention to these enthusiasts of violence, and address two primary questions: (i) what justifications are put forward by the men (so far, women have rarely been involved in such episodes of 'iconoclash') who terrorize artists and destroy works of art, beyond delineations of unofficial party mandates and politics of right-wing organizations? (ii) how do they negotiate the extreme social reactions towards themselves, which range from considering them intolerant fanatics to martyrs and models? Looking at violence through the eyes of the attackers, I argue that a common theme which defines the microsociological make-up of this violence is the search for glory, understood as the individual take on an epic collective imagination, or to put it more simply, as the internalization and creative appropriation of a cult of the hero. The rage that outlines this heroism is sought, among other things, through the deep rooted and problematic realms of gender, sexuality and politics. For instance, by claiming to defend women's 'honor' as they discredit works of art, these men act out their vindications and fantasies, at the same time symbolically reassert their domestic identities and expectations tied to work and family-'heroes in the bedroom', to paraphrase the old Sanskrit expressions referring to 'house heroes'. ${ }^{2}$ Regrettably, due to constraints of space, this study holds back from approaching a very pertinent issue from the other side, i.e. the contradiction that women in general may not perceive these actors as their heroes despite the latter's claim to be the protectors of their 'honor'.

Public and macro dimensions of attacks have been expressed in debates in the media and in the Parliament within the limits of democratic governance, electoral politics, freedom of expression and religious sentiments. ${ }^{3}$ In contrast, the attackers' life worlds remain less accessible but equally potent, offering powerful referents for defacing imagery and emerging a victor. Escalation of attacks throughout the country points to the localized fabric of role models and heroes such as a Niraj Jain in Gujarat (although inspired by Diwakar Rawate in Maharashtra), Afsar Khan in Hyderabad, and so on. Despite widespread condemnation, these individuals often enjoy a degree of respect at the local or regional level.

5 This article stands at the contested intersection between heroes and role models, where a hero is understood as a man, real or fictional, of exceptional courage or ability, admired for his brave deeds and regarded by others as an ideal. Role models are non-fictional characters whose behavior and success set an example to be emulated by others. Virtue is not a necessary qualification of the former: a hero may not be a role model, he may not be a 'good man', he only needs to be extra-ordinary. It is in the essence of heroes to be unique, therefore inimitable. The article is rooted in this ambivalence, based on the fantasies and justifications of attackers. Questions related to modern day heroes, haters and attackers, as achievers and role models, would not be so engaging, emotionally 
disturbing or politically challenging were it not so potent for the changing contours of free speech in India.

\section{Outline of the assault: playing the protagonist}

6 As a form of violence, attacks on art in India are a unique and relatively new form, differing from communal riots, political demonstrations, student agitations or labor union unrest. ${ }^{4}$ They involve a blend of religious, political, symbolic, economic and personal aims. Less planned and smaller than a riot yet more organized than a street side assault, the phenomenon of violence on art lies somewhere in between. Stoking claims of religious sentiments being hurt, these attacks are both inter religious and intra religious. Thus, a Hindu mob is as likely to attack the work of art by a 'deviant' Hindu artist as that of a Muslim artist allegedly disrespecting narrowly construed Hindu religiosity. The build-up and preparation of these attacks happen when a 'source' informs the group of the 'event', or it learns of the occasion through the media, leading to a collective distortion and interpretation of the works, based on the reductive denominator of religious affiliation, independent of the artist's intentions. Thus begins an agitation around perceived disrespect, humiliation and threat. The characteristic form of public manifestation of violence involves a daylight agitation by five to twenty men, belonging mostly to the age group of 40-60 years, generally but not always armed with lathis (sticks). The violence goes beyond inflicting wounds with physical force, and includes physical and/or verbal abuse: tearing a painting, assaulting actors, ripping film posters, inflicting property damage in cinema halls, burning books, shouting abuses and religious slogans. In the main, this form of violence on artists by religious nationalists is to be regarded as a process: a spill-over of larger ideologies while also, at the same time, creating spillovers of its own, cumulative, boundless and often internalized violence (Lawrence \& Karim 2007: 13-17). The source of legitimacy, heroism and glory of this violence originates from the point of view of the instigator or what Samuel Klausner has called 'victim-defined spheres of violence' (Eliade 1987: 268-271). For the attacker and the perpetrator, this is glorified in the name of protection of faith and the divine, a crusade. Also, control and representation of women has been mobilized as a significant justification for attacking art, and stands at the intersection of religious, national and domestic narratives of heroism.

One feature that sets violence on art apart from other forms of communal agitations, like riots, is that physical violence here remains solely one-sided and imbalanced, i.e. artists have rarely reacted in a similar manner by using physical force. The ultimate aim of such vandalism does not necessarily lay in the destruction of the creator but the creation, to 'scare the artist away', instill terror, 'police' the boundaries of visual productions and viewership in the society, and thereafter emerge as the savior, the hero. The role of the police in most instances has remained peripheral due to corruption and speculated reasons of influential position of the political parties and groups the attackers belong to. It is this deficiency of state support and guarantee of impunity that makes the artist susceptible to such attacks. What is more important, the police may play along in hailing the attackers as heroes. The present article focuses on the men behind the three most well known cases of attacks in India in recent years: the incident at the MS University in Baroda in May 2007, attacks on painter M.F. Husain since 1998 and the Hyderabad attack on writer Taslima Nasreen in August 2007. These attacks provide three instances that can 
help us understand the development of a pattern of attacks on art. Earlier attacks included the Vishwa Hindu Parishad (VHP) assault on SAHMAT's Hum Sab Ayodhya cultural sit-ins in 1993 at the height of the Ramjanmabhoomi/Babri Masjid agitations, violence against Deepa Mehta's film Fire and the disruption of the shooting of her film Water, among various other instances.

Besides, 'hurting religious sentiments', celebrated and hailed as the ultimate cause, I argue that these occurrences are neatly tied to the narcissism of men who indulge in the same. Heightened and varied media attention and perception confuses the hero and the villain. Whatever the jury and the judgment, it is the attackers instead of the artist or the critic who emerge as the lead characters in any consequent description of the broken, damaged, defaced, repaired, remade, re-described piece of art.

\section{Fame and the female: the heroism of doing 'God's work'}

Even six months after May 2007, the name Niraj Jain evoked strong responses in the Fine Arts Department of MS University in Baroda (MSU), and proud support from his defenders in the Bharatiya Janata Party (BJP). Jain, from a small time lawyer gained notoriety as Gujarat's ex-President of the Bajrang Dal, Joint Secretary VHP and Secretary BJP (Jain 2008). ${ }^{5}$ Transformed into a militant defender of Hinduism, Jain was one of the accused in the violence that followed the Godhra carnage in 2002 (Concerned Citizens Tribunal 2002). As a 'preserver of pure Hinduism', he was in the news for having brandished a revolver and thrown eggs at the state Education Minister for including them in school mid-day meals (Dharkar 2007). But it was the MSU art case that 'finally' brought him to spotlight, and 'people recognized [him] as a hero'. Jain barged into the University campus along with the state police, where he abused and threatened both the faculty and students, and ordered three paintings to be removed from the ongoing student exhibition. Even amongst party and organizational cadres, Jain had acquired a reputation of a fierce, violent, intolerant defender of Hinduism.

10 A big, red tika (holy mark) covered his forehead, a cluster of red holy Hindu threads tied on the wrist, Niraj Jain, by then famous in Baroda, was a Hindutva supporter recognizable from afar. A man in his forties, he had the gait of a confident, vain warrior. In plain white pants and shirt, he gave the impression of a man who dressed up for his role. Jain was not yet a star in Gujarat, like Babu Bajrangi ${ }^{6}$ or Narendra Modi. Nonetheless he was an assured, unabashed version of someone who wore his dreams on his sleeve, hoping to be a star but undecided about what kind. He was convinced that responsibilities of governance and legalities did not amalgamate well with the individualism of a hero, justifying violence to be outside the norms of a democratic polity while still working around to profit from the nation's legal apparatus. Jain claimed, 'All this [party positions] is OK but I need no political platform to do my task. If I see a painting like this anywhere, even if I'm not part of any party, I would put an end to such things. Because I know it is God's work. I am a person well versed in law. I know very well how to use law'.

11 Seemingly animated by a desire to be a hero for Hindus, he claimed to be prepared to sacrifice and stand alone even for temporal and idiosyncratic motives such as transient fame or a party ticket. Most striking was that a large part of his own construction of 
heroism was sought through and over the female presence, body and sexuality. It is this aspect that also in part explains his discomfort over particular works of art.

12 I think I took him by surprise when I approached him introducing myself as the 'researcher from Paris' he was scheduled to meet. 'But you are an Indian woman, also young (...), what are you doing here?' His initial surprise and relief was soon replaced with suspicion. He asked the first questions to fathom if he was being tricked 'by the Tehelka people' like some of his 'friends'. ${ }^{7}$ After three ID cards and a few minutes spent on my family history, he braved the recorder, and settled down to 'ask whatever you want, I have no fear'. Jain introduced himself, balancing his pride, confidence and calm. The first words he chose to describe himself were a reaction against the English media's portrayal of him: 'I am basically an open-minded person'. Jain described his role in society primarily in relation to a 'higher reality', his work for Hinduism as 'God's work'. The higher reality that is not accessible to ordinary mortals was thus to be undertaken by the 'chosen few', a belief that emanates from tales of heroes whereby the latter may sacrifice themselves so that others may live or so that they themselves may live in other's memories. Jain was unwilling to delve much into the subject of his profession as a lawyer, which he deemed secondary but still considered as 'God's work'.

13 Jain was savvy and instantly eloquent about Vivekananda and the Bhagavad Gita. These were sources of his Hindu pride and a substantial justification that God was watching him at all times, and thus 'I am likely to never do anything wrong and God in turn helps me'. Jain was convinced of Hinduism's superior position in the hierarchy of religions, its defining feature being tolerance. '[Tolerance] comes in Hinduism, this does not come in Muslims. Islam says that if someone slaps you, their hands must be cut. In Christianity as well, they don't forgive anybody. Hinduism is open-minded, everyone has a right to speak and talk. This is why Hindu is suppressed everywhere'. Jain's personal relationship with violence offers a more sharpened understanding of his actions at MSU, which comes from both a family history of penance and a self-inscription in the Hindu caste order that bypasses the ahimsa (non-violence) preached in Jainism. For Jain, "being a kshatriya (warrior by caste) was in [his] blood', while 'Jainism was only adopted by [his ancestors] for what had happened. In any case it was part of Hinduism'. 8

14 Like most members of the Hindutva network, for Jain too this perception of his own tolerance was simultaneously shrouded with doubts of it being a sign of weakness towards the Other, an example of virtue becoming a disability. Instead of justifying the violence meted out by Hindus in the name of tolerance, Jain focused on the suffering which tolerance brought upon Hindus, for this talk of shared sufferance would bring the Hindus closer together. For him, a cornerstone of Hindu society's sufferance was the angst about sexual concerns, control, its representation and all its associated conservative moralities. 'The biggest problem of our tolerance is that anyone can portray our gods naked. They can abuse any Hindu woman or sister, and abduct them'. The responsibility of doing God's work, belief in being the hero chosen to 'save society and women from moral degradation' and its associated anxiety prompted his 'intolerant' reaction to the paintings. 'It is not my responsibility alone; it is the responsibility of the entire society to uphold respect of our mothers and sisters. I defend Hinduism because others are scared to do so. The person who suffers injustice is worse than the person who commits it. So here I am'.

15 'Art is something which gives me pleasure. When I feel something in my heart, those are called paintings. What was depicted in those things that they called art were not gods. A 
man and a woman were shown having an intercourse'. His aesthetic understanding was limited to very literal, figurative aspects of the works. Repeatedly describing them, he conveyed the extent of his disgust, reasons for the attack, his discomfort with sexuality, the extent of his concern with women's shame and the need to define boundaries of public and private. 'In the linga [a phallic symbol of Shiva], he (the artist) kept his own photograph suggesting that he is having an intercourse with Parvati. Now would any person do this to his mother or show his wife like this? You are a lady. What do you feel if someone were to show you like this?' Swiftly positioning his audience as a victim, Jain saw himself as the 'savior and friend of the voiceless', the 'protector of the oppressed'. He continued with authority, 'I believe till the time a woman is covered in clothes she is beautiful. After she has taken off her clothes, she is beautiful and desirable for her man only. Her beauty belongs to her man. Her beauty is not for the society'. The hero's view degraded the unclothed, nude woman and, in doing so, aggrandized him in his own eyes. Ideas of public and private spheres, broadly believed to be a distinction between domestic and non-domestic life (Mahajan \& Helmut 2003: 205-28), laid central to Jain's thought and actions. Both implicitly and explicitly, the conviction was perpetuated that these spheres were sufficiently separate, that the public and the political could be discussed in estrangement and with entitlement, i.e. through disassociating the two along with making rightful claims on what constituted political and public. 'I say that if you want to enjoy nakedness, limit it to your bedroom. That is where a woman's beauty lies'. Jain granted agency to the woman -after all, it is she who takes off the clothes-but at the same time he suggested that the boundaries of her action were to be governed and controlled.

Jain saw himself as a protector of Hindus, but also the guardian of women's role, respect and social uplifting. His retaliation was against a painting of a goddess where, for Jain, godliness was superseded by femininity. It was the woman who needed to be saved and not the reverence towards a goddess who saved humanity. 'Painting mother Durga naked, showing a child coming out of her vagina whom she is killing with a trishul-isn't this a kind of fetus killing? Can any mother kill her own child?' India's art history did little to deter his understanding of aesthetics, Hinduism, women or violence:

When Khajuraho ${ }^{9}$ was made, teaching was done only through sculptures. I have seen them. Did you ever feel irritated when you saw them? At any time, did you feel like having sex when you were around those sculptures? Did you feel it was disgusting? In Ajanta-Ellora [caves], can you see nakedness anywhere? If you want to see art then come with me to Pavagadh. I am a trustee there.

17 Jain conveyed his power and legitimacy as an art lover and the degree of his importance in the life of the community in which he lived. The hero's authority was so grand for himself that he was lost in admiration, but he referred only to the beauty of all that was erotic in art and in the temples:

Nothing else is visible in it [the art works he attacked] except sex. In Lord Vishnu's painting, he has shown Vishnu holding a penis in one hand and surrounded by many other penises. Is this called a painting? Has our art fallen to such levels? After Darwin's study of evolution, we became a species that started wearing clothes. Will we still go around showing our penises?

The more he claimed his disgust against the 'sexually immoral art and the need to protect Hindu women from such degradation', the more he spent time speaking about them. Words associated with intimate desire and excitement, generally considered culturally inappropriate for a 'public' discussion, dominated the monologue. Jain was much more 
comfortable talking about the perceived bawdy sufferance than about religion per se or violence. He focused more on the associations made due to the discomfort of lascivious works than on the divisions of religious or ethnic disorder. Jain was convinced that losing one's respect by seeing one's body and biology belittled in the name of art and the hurt sentiments of worshippers of that iconography was a shared experience of Hindu men and women alike. In turn, this conditioned the maneuvers in his speech, by being aware that ultimately, he was talking to a Hindu woman. Talk of disrespect and shame due to these visual depictions would earn him another follower, seeker and supporter, whereas detailed illustrations of his own acts of violence could risk a division or retaliation from his audience. He interpreted art and spoke in a representational manner, but not for the nation, strictly for the 'entire Baroda society'. Language played an integral role in defining territories of influence in the construction of his heroism through these attacks on art. Jain was conscious of addressing the Gujarati speaking and Gujarati educated audience. For it was he who could understand their pain, and take their voices and distress 'to the highest level, and seek justice'.

As a mark of service to society and of the extent he would go to save this 'degeneration', Jain elaborated on the professionalism of his cause: 'I wrote to the Pope asking him to give me his observation on these paintings. After he received my email, from the next day the media of the entire country stopped writing on the issue. Sonia [Gandhi] also shut her mouth. Why? Because the Pope asked them to stop, agreeing with me that it was disrespectful to Lord Vishnu'. He returned to the issue of carnal discomfort that women would face, if they encountered the art pieces. For his own, he suffered to save the society. Jain believed that heroes were rebels, hard to accommodate in a well-ordered state, not the ones who gave in to what the world might know, believed or stood by. Jain had his own version of the MSU exhibition, contesting that it was an exhibit for sale and not for examination evaluation as 'alleged by the Dean'. This way, though the justifications of his acts remained unchanged, he believed that he also could not be made accountable for the disruption, for his justification of the university 'event' did not correspond with those against whom he reacted.

Beyond seeing the attack as his achievement, Jain was less concerned about the impact of actions on the students, disruption of the university system and the works of art, which were 'now sealed in a room'. In highlighting his own importance, Jain never restricted himself to one-line statements. For example, he did not limit the response to 'They (the university) were not troubled at all'. Rather he added how and why the impact was really not much. For both of these, Jain sought reassurance in women's voices, and was comforted by his newfound supporters from 'around the world':

An Australian sister had come to write an article about me. I told that woman that I will show you the photographs of the paintings. After seeing them, tell me if I am wrong. After she saw them, she told me, 'Mr. Jain you are a coward, you should have slapped that man-why didn't you slap him?' I told her I only created a little noise and so much hangama [noisy chaos] happened. If I would have slapped him God knows what would have happened? Now you tell me, am I right or wrong?

Men and co-workers played no part in Jain's narration of his heroism. He did not need them, did not need to protect or control them. 'The day the women of our society are neglected, the day their perversion happens, it's the end of Hindu society. I have to save them from this. Hamara kya hai (what is it to us [men]?) A real man is one who can save his woman from the society's gaze'. 
22 Any deliberation on the cult of the hero anticipates ways of thinking about mortality where the hero, in his pursuit of immortality, is willing to expose himself to mortal dangers to the extent of social unacceptability, disregard and public contempt. 'I am famous now. People know me and have written about me in newspapers all over the world. I know that the English media will write only against me, they all are against Hinduism'. On the contrary, sections of the Gujarati media hailed and praised Jain's selfless act against the 'immoralities of youth and selfish professors'. Jain took solace in this acceptance, and found a rationale for believing in his guardianship of Hindus in this moment of glory.

Arab Times, Dawn of Pakistan and others in their editorials have abused Hinduism. They want a chance to abuse Hinduism. Arab Times wrote against me that I have raped the artist. Yes, Niraj Jain is an art rapist. What did I do? In Calcutta they put hoardings against me. They made my cartoon saying 'art rapist' [...] They have even fired at me. I feel very happy reading all this because through this, people who do wrong at least come out in the open. [...] I believe that the work I'm doing is not wrong. Whomever I'll speak to I will look into their eyes and speak. If these things continue, who will protect the coming generations? Somebody will have to uphold the ideal and tell them that this is what we were ... if there was a Ravana then only people realized that Rama is like that. It is because of Kansa that Krishna was nice. Somewhere someone has to sacrifice. This is why I've taken birth [...], after this I could face my own women.

\section{Playing the tiger's tail: subjection as a route to self- aggrandizement}

Unlike Niraj Jain, Diwakar Narayan Rawate believed that he was a true role model, not a hero who was unique or extraordinary.$^{10} \mathrm{He}$ was a Maharashtrian but, more significantly, he was a trained, proud, loyal follower of Bal Thackeray's Shiv Sena, ${ }^{11}$ 'right from the day the Sena was born in 1966'. His pro-Maratha stance translated into a socio-political discourse that preached 'Maratha equality' rather than 'caste-equality'. In 2008, he even supported reservations in the State Assembly for Marathas on grounds of economic rather than caste status, a demand informed by his own position in a higher caste but a lower economic status. Now in his fifties, Rawate was highly experienced and tactful in dealing with (un)constitutional mechanisms and backyard party politics. Since 1966, he had slowly and steadily climbed the party ranks: from being 'one of the Sena boys', he presently served as a senior leader and MLA, although he was still some notches below being called a political star, the kind whose phone would be answered by someone else or followed by chamchas (sycophants). For the liberals and the educated English language press of Mumbai, he was notorious as a riotous, violent bigot while the Shiv Sainiks (Shiv Sena activists, literally soldiers) and sympathizers of Maratha pride hailed him, and took inspiration from his dedication to their cause. Juniors in the party aspired to his role in the organization of the party's violence, and also hold in high regard his loyal service to the party chief Bal Thackeray. Like Jain, Rawate compensated his lack of economic power with the local glories accompanying his cause and the ensuing violence. Rawate's construction and consciousness of his self-image, as a local role model for the 'Sena boys', drew from the narcissism of the leader-follower relationship. The power and omnipresence of Thackeray in Mumbai particularly appealed to Rawate, although he did not qualify himself to fill Thackeray's shoes, but rather was consumed by his vision and stature to heal the wounds of Maharashtrians, the characteristic rhetoric of polarization, 
uniting followers against the outside enemy. Despite a strong sense of self-esteem, if not egotism, Rawate acknowledged himself as a model of obedience: follower, son, devotee. Subjection to the leader was here the pre-requisite, or the condition of possibility of selfaffirmation. Ironically, for a rabidly anti-Muslim party such as the Shiv Sena, this empowering subjection was reminiscent of constructions of the Self in Islamic socioreligious movements (Audrain 2004, Mahmood 2005).

The core of the Shiv Sena's ideology was his most passionate cause, the 'issue that Bala Sahibji raised'.$^{12} \mathrm{He}$ explained his politics:

Maharashtra was developed; states were divided linguistically according to the Constitution of India. So, naturally, the right of 'sons of the soil' is clearly mentioned in the Constitution. Though our Constitution says that everyone in the country can settle anywhere, they do not have the right to deprive the sons of the soil people. After the state was created, everyone started coming to the city, occupying jobs thereby depriving Marathis of their rights. I was part of the first Sena rally [...] Bala Sahibji received tremendous response.

The story of his own aggrandizement was intimately tied to the growth of the party and, unlike Jain, Rawate devotedly used 'we' in his narration rather than ' $I$ '. He devoted himself zealously to the service of the Maharashtrian community by working for blood camps, hygiene and health facilities, or by playing judge to local family quarrels, etc. He believed that this personal relation with the Marathis explained the rise of the Shiv Sena. However, not one to believe in peaceful political advancement, Rawate was a firm advocate of using physical force to get things done: militant morchas (demonstrations), bandhs (strikes), use of dadas (dons) and pehalwans (wrestlers, and more recently bodybuilders). ${ }^{13}$

We are militant. We call ourselves sainiks so we obey our chief. Whatever he decides, we are ready to sacrifice our lives for the cause. He was the first one in India to do politics like this, without caring for consequences, and brought justice to the people of Mumbai. The strength of Bala Sahibji is such that he can paralyze anything in the city. The moment he puts his finger down and gives a go, everything can be started again.

Rawate was ecstatic, for the city worked around the whims of his hero. Admission of his own pride thereupon lied in the Shiv Sena's threat of alternative governance, of which he was an important part. Rawate summarized that his religion was Maharashtra and his God Thackeray. He shared Jain's hatred for the Muslims, echoing similar sentiments: Muslims were outsiders, violent and fanatic, and Hindus suffered due to their own tolerance.

Unlike Jain, however, Rawate made no claim for his love of art or freedom of expression to justify the attacks:

Art and all these small matters don't bother me too much [because] artists and singers don't encroach upon our working space. The only time we take action is when they do other than just sing, paint, act or anything else. When they give their views not required by the society and those we disapprove of, then we retaliate. These days, artists, filmwallahs, think they have become very important. We just do things to keep them in check.

Following the Shiv Sena working style of threats and physical coercion, proving allegiance to his hero by seeking issues that matter to the master, Rawate had spearheaded various violent demonstrations. These were 'nothing new' to him. 'The man sitting in front of you broke the first billboard on the road in Mumbai twenty years ago'. Shiv Sena seniors and supporters, from whom Rawate got the large part of his self- 
esteem, rewarded him by promoting and positioning him at various press conferences and public platforms. 'Every time I indulge in these acts I feel I am doing a service, setting an example, my blood boils and I feel powerful, that I can make a difference'.

While violence is an integral part of the Shiv Sena's political culture (Hansen 2001), Rawate's self-representation as an 'ideal' and a 'role model' could be ascertained through his description of how artists had hurt him. Like Jain, Rawate's sentiments revolved around a gendered explanation, but his female figure was not his companion or an object of sexual desire. She was the revered mother and the vulnerable daughter. Justifying his repulsions, he delved on the duties of an ideal, exemplary son to his 'mother' land, 'mother' tongue and 'mother' goddess and how his example would 'inspire the young generation to show respect'. Artist M. F. Husain's representations of unclothed Hindu goddesses have, since 1998, invited sever ire of the sainiks. Violence against Husain's work and property and even threats of killing did not invoke any moral anxiety on Rawate's part. To the contrary, assault in such a circumstance was every 'sainik's moral duty to save the 'mother goddesses' from 'such Muslims': 'We will not leave him if he dares to step in our country. If he comes in front of me I will shoot him. It is simple. My religion is my mother; my faith. Who has given him the right to draw $m y^{14}$ mother naked? It is because of Muslims who buy his paintings for millions of dollars that he paints such things, just to tease us'.

Religion was overshadowed in Rawate's narration of the various attacks on Husain's representations of Hindu goddesses Saraswati, Durga and Sita by the over emphasis of a relation he sought with the opposite sex and the discourse of preserving women's virtue that also provided the justification for violence.

My Hinduism is if I see my daughter in you (...) you should know that we are your saviors. Not again will a Muslim be able to treat my daughter in an unfair manner. In Islam a seventy-year-old man can marry an eighteen-year-old girl. We don't do that.

31 Rawate was also involved in the obstruction of Pakistani singer Ghulam Ali's concert in 1998. His elaborations focused on the assumption of the hate shared by 'all' Indians against Pakistanis, as well as on the universal feeling of 'motherly concern', thus bringing people to realize that he was speaking their language, reflecting their hurt. 'Insult of my mother is not described anywhere in the books of law. Is there any court in the world that would allow one's mother to be treated like this?'

Serving the cause of a modern nation state, Rawate's attacks on artists is irreducible to symbolic nationalism or a whim to get famous. While these attacks were intended to scare the artists away, they also served to assert the integrity of his value and ideology. Jain was content in the flowering of his fame after the attack and cared less about the broken image: his own or the works of art. But Rawate, a trained follower, seemed less concerned about his own fame. He invoked his own unique form of justice, notwithstanding the orders of the State High Court supporting the artist's right to free expression. 'If I believe my religion is my mother so this should be respected. That is why court is blind. It has no feelings. The only justice is that Husain should paint his mother, sister and wife like this. Then only I will consider [his paintings] as art'. The issues revolve back to the protection of the private sphere, the sphere symbolically inhabited by women: 'The paintings are a problem because your bedroom should not be open to anybody. If you don't agree with me then what is the message you want to give out to people?' 

immune to criticism: 'English media has attacked Sena since the time it was born, they attack today and I am sure they will do so tomorrow. But they are not our concern anyway'. If he could claim that, it was because 'Bala Sahibji' had inspired him to work against all odds: criticism, the Constitution and the law. His commitment was his achievement, the only way he believed that he could inspire the 'next generations to save their women'.

\section{Between opportunism and self-sacrifice: the muscle- man as 'Islamic' hero}

'Muqtada' Afsar Khan was a 58-year-old locally well-known MLA of the All India Majlis Ittehadul Muslimeen (All India Conference for Muslim Unity, AIMIM), a Hyderabad-based Muslim political party. ${ }^{15}$ In many ways, he is the Muslim equivalent of Rawate although he did not share Rawate's accessibility for interaction. He belonged to the community of pehalwans, economically sustained through what is euphemistically called 'land or real estate business', but allegedly involving land grabbing activities. Along with his brother, famous in Hyderabad as 'Meraj Pehalwan', Afsar Khan shot to the limelight following the 'boom' of their 'land business'. Hyderabad provided the context of Khan's growth and his importance within the local Muslim community. In a city with a history of communal violence, keeping up religious pride has become a major issue. Since Khan was 'always more interested in Muslim issues like water, schools, colleges, etc.', he decided to join the AIMIM thirty years ago, 'because I was also politically inclined'. The AIMIM, one of the oldest surviving Muslim parties in India, defines itself as the 'voice of Indian Muslims'. Today the old city of Hyderabad is the party's stronghold. Khan, like most party members, owed allegiance to the party's towering leadership: Sultan Owaisi and his sons, Asaduddin and Akbaruddin. ${ }^{16}$

Well-built and heavy voiced, like many pehalwans within or outside the AIMIM, Khan was reputed as violent, and was often in the forefront of agitations in the city. In his capacity as an elected MLA from Karwan, Khan had been involved in notable cases of violence and had his name booked under various police charges including attempts of murder. However, his position as an MLA gave him an advantage in and out of violence since he is part of the 'system'. In July 2008, he was arrested for firing from his licensed revolver protesting against the demolition of an illegal structure by the city's Municipal Corporation; he allegedly roughed up doctors at a city hospital in December 2007 for not providing 'proper' treatment to a child. In March 2007, the editor of the Urdu newspaper Siyasat was harassed after his newspaper spoke about Khan's 'land grabbing activities'. Despite these, Khan was confident that 'people like my style of politics otherwise I wouldn't be here serving my third term'. Rehearsed words of a politician followed: 'Their love is important. I guard it and work for them'. Violence as an instrument of politics was what he and 'his people' agreed upon 'since I don't care for police, court cases or the law'. He proudly took the discussion to the core theme of this article: 'But of all these incidents the most famous one, the one that you must have heard of is Taslima Nasreen's. That was an important opportunity for me and probably such a big chance ${ }^{17}$ will never come again in my life'. What is truly remarkable here is how genuinely Khan acknowledged his personal motives in targeting Taslima Nasreen, although this self-proclaimed opportunism confining to cynicism did not preclude other motives of a more moral or

South Asia Multidisciplinary Academic Journal, 4 | 2010 
ideological nature. And again, as with Jain and Rawate, women were integral to Khan's self-representation and projection as an exemplary personality. Except that this time, women no longer appeared as weak creatures in need of protection; they were constructed as potential threats to the 'natural' order of things, which had to be contained by any means.

Exiled and famed Bangladeshi writer Nasreen was in Hyderabad on $9^{\text {th }}$ August 2007 for the release of the Telugu translation of her book Shodh. 'I got a call from our Salar-e-Millat (commander of the community), Sultan Owaisi, that you go and protest because Nasreen is in Hyderabad. So I went and protested. The entire party was called to protest against this, but I was the first to reach'. It was only much later in the interview that Khan invoked a personal reason for leading the attack: 'I had problems with her writings on issues of my mother, my sarkar (boss) Prophet Muhammad and especially what she had to say about my Muslim culture, that it is not necessary for women to wear a burqa. For things like these it was necessary for us to protest in Hyderabad. I protested on behalf of my congregation'.

After the attack, the AIMIM filed a police case against the writer, however, not on grounds of 'hurting religious sentiments' but on the technicality of her visa restrictions and travel. A case was booked against Khan as well, 'because I hit her and I give no importance to this court case'. Khan proudly explained how he picked up chairs, tables, flowerpots and 'anything that I could get my hands on', along with 'some very bad abuses' that he threw at Nasreen during her press conference in the city.

In defense of his faith, Khan's associations with his religious group revolved around stereotypical categories like 'good Muslims' and 'bad Muslims', overshadowing individual identity traits. For Khan, Nasreen was no more than an 'unworthy Muslim' and violence was the 'only way the infidels can be taught a lesson'. In any case, '[I]t was very little that was done to that woman, if I had got a chance I would have done a lot more... I could have gone till any extent. I don't care who the offender is, a woman, a man whoever does misdeeds against Allah I am not going to spare that person'.

Starting with an almost cynical discourse, Khan gradually drifted towards a completely opposite form of self-presentation, which emphasized his readiness to self-sacrifice, and freely drew its inspiration from Islamic idioms of heroism and martyrdom. Despite their extreme disregard for Muslims, Jain and Rawate professed a similar conception of heroism as a form of self-sacrifice to the Creator, as their claim to be committed to 'save the mother goddess' suggested. For Khan, this spirit of self-sacrifice would be 'natural' among Muslims: 'inspiration to fight for Islam is in the blood. I am a Muslim and this inspiration to fight for the religion is in the body, this is in my iman [faith]'.

While religion provided the most important parameter of identification for men indulging in attacks, the boundaries of what they defined as 'community' were fluid. For example, Khan began with an all-encompassing 'Muslim community' including faithfulness to universal Islamic brotherhood: 'The Muslim community cannot say anything negative or against what I did to Taslima. A message was sent to the world that even in Hyderabad there are people who love Allah, and cannot tolerate any misdeeds against Prophet Muhammad'. This translated to the city he belonged to. Thus, his service to the 'Muslim community' remained tightly bound to the geographical limits of Hyderabad: 'I will not go to another city for defending Islam like this. They have other people there to save Islam'. Following which his praise, allegiance, importance was highlighted through the political party he was associated with: 'I will follow the 
instructions of what my Majlis asks me to do. I have a life associated with a political party. I am tied to my work'. Finally, like Jain and Rawate, Khan saw women's respect, adoration and obedience as the ultimate mark in self-realization as a hero: 'Many of the women in the society where I live are thankful and happy with what I did. And if the whole world, the Muslim community, liked what I did then it is natural that my wife liked what I did. I feel proud of what I did and so does she. That is important for me'. He proudly stated that his organization was working on women's issues like, 'we save them, we see to it that they have a good environment to live in'.

41 A characteristic trait of 'attackers as achievers' that emerges is the complete denial of any extra or negative impact of their action other than the kind desired by them. Khan was convinced that 'Taslima will never come again to Hyderabad or even write such a thing again'. Bound with the idea of sin and complete assurance of power over women, he was nonchalant about the extent of his violence: 'Many people told me that I shouldn't have raised my hands on a woman. Even though we have made progress in education of our women, all the other women have come to know now that if they make a mistake as far as our boss (Allah) is concerned this will be their fate. What I did was absolutely just'. Like a professional pehalwan who wrestles for the public or the politician performing for his people, Khan spoke as an entertainer who could not let down those who expected a show. This partially explains the justification offered by Khan for his own violence: 'I am here to serve the people'. He said, 'The juniors in my party like me a lot, public also wants this, this is the mood. The public wants that I keep playing this role, so if the public wants me to do something then I must be able to fulfill their expectations'. In cases of art attacks, self-constructions of heroism do not stem from a narration of the incident as a tactful display of violence, but rather provide ways of thinking about (im)mortality and the possibility to transcend one's life, to become somebody: 'After the Nasreen attack, the public appreciated me a lot, many people came to congratulate me, I got calls from all over India, I even got calls from out of India, wherever people watched me on the television they congratulated me. Many TV channels came to speak to me like NDTV, Aajtak, Star TV-everybody contacted me'. Khan emphasized the importance of his deeds and portrayed himself as an asli sher (real lion), who inspired more attacks like these: 'After what I did in Hyderabad only then in entire India was there a voice against Taslima like in Bengal, Bangalore, so the retaliations picked up'.

\section{Conclusion: the transient glory of modern-day iconoclasts}

Attackers of art and artists consider themselves as exceptional, and yet exemplary, by virtue of their commitment to suppress opponents, to 'save' their religion and their women, or to resist an unjust political system. While violence is not new among Indian politico-religious activists, the introduction of art, camera, media and the pretext of women's honor have been providing convenient arguments for heroism and achievements. In all three accounts, the attention generated by the mass media played an important role in publicizing and consolidating the attackers' self-representation as emerging heroes. It was not so much the content or the criticisms that affected these men, but the very fact that their name appeared in the media. Their names have been tied to every subsequent narration of the attacked piece of art or artist, strengthening the belief that just as they knew about the 'heroism' of 'people' who burnt Rushdie's books or 
protested against the Prophet's cartoons in the Danish Jyllands-Posten, likewise their acts would be 'known to the world'. For Hindu attackers, 'the Muslims should know that even we can defend our faith' (Jain's interview) and for Muslim attackers, 'the world should know that even in India there are those who fight the infidels' (Khan's interview). However, strategies of violence assume dramatic, unpredictable consequences.

In attacking art, where risks of punishment or physical harm to attackers themselves are low, attackers may find a shortcut to fame. Individual gains of such activities outweigh the risks of punishment posed by the state, law or society at large. State authorities in India, including the judiciary, have notoriously overlooked the nature of such violence, favoring electoral appeasement over justice. The National Academies of Art, on the other hand, have referred the matter 'out of their purview', ${ }^{18}$ leading to an increasing vulnerability of the media to public expression and its acceptance of violence. However, even though attackers' narratives told a tale of heroism and exemplarity, these men were in fact hero worshippers, considering themselves local embodiments of national figures. Their heroism or construction of exemplarity was limited to linguistic boundaries for they were aware of their own limitations. These men were not national, immortal figures; they knew that they shall never be. Although they saw attacks on art as modern day achievements, they rarely invoked the idea of a nation. The nation emerges, nevertheless, through the gendered metaphor of 'Mother India' (Ramaswamy 2003).

The place of art in society now increasingly resembles dramatic market practices of consumption, ownership and entitlement whereby showcasing rejection has also been intensified. Furthermore, though the attackers consider violence on art as part of the 'public sphere', they aim to make women aware and proud of this violence-what we could call the 'this-time-we-are-doing-it-for-you syndrome'. While the 'liberal, secular' world mocks them, they find solace in the bargain that they could foresee and defeat danger, punish the guilty and honor faith and women. These iconoclasts are simultaneously admired and marginalized, being more often characters of momentary veneration than holders of real power.

The rhetoric of these self-professed role models and heroes is adjusted to cater to the moral values, emotional needs and religious aversions of their audience. That violence on art is unconstitutional is a banality, but being enthralled by men who see it as the source of their heroism is intriguing. Bertolt Brecht wrote that it is an unhappy land that looks for heroes (Halpin 2006). In the midst of the crisis of communal politics and religious fundamentalism the process assumes a dramatic, complex resonance. Perhaps it is only in times of quandary that heroes and role models prosper. In any case, the mass media is as instrumental in nurturing the transient glories of modern day achievers as it is to send them back to oblivion - or to the bedroom-, where so many of them belong.

\section{BIBLIOGRAPHY}

Audrain, Xavier (2004) 'Devenir 'baay-fall' pour être soi: le religieux comme vecteur d'émancipation individuelle au Sénégal', Politique Africaine, 94, pp. 149-165. 
Austin, William; Worchel, Stephen (1979) The Social Psychology of Inter Group Relations, Monterey: Brooks-Cole.

Blom Hansen, Thomas (2001) Violence in Urban India. Identity Politics, 'Mumbai' and the Postcolonial City, Princeton: Princeton University Press.

Bunsha, Dionne (2006) ‘A Serial Kidnapper and His “Mission”, Frontline, 23 (25).

Concerned Citizens Tribunal (2002) Crime Against Humanity: An Inquiry into the Carnage in Gujarat: Findings and Recommendations, Vol. 2, Mumbai: Sabrang Communications.

Dharkar, Anil (2007) 'Beauty and the Beast', Times of India, 17 May.

Eliade, Mircea (ed.) (1987) The Encyclopedia of Religion, Vol. 15, New York: Collier Macmillan.

Guha-Thakurta, Tapati (2004) Monuments, Objects, Histories: Institutions of Art in Colonial and Post Colonial India, Cultures of History 2, New York: Columbia University Press.

Gupta, Dipankar (1980) 'The Shiv Sena Movement: Its Organization and Operation, Part One and Two', Social Scientist, 8 (10), pp. 22-37.

Halpin, David (2006) 'Why a Romantic Conception of Education Matters', Oxford Review of Education, 32 (3), pp. 325-45.

Hoskote, Ranjit (2004) 'The Mob as Censor', The Hindu, 11 February.

Jaffrelot, Christophe (1996) The Hindu Nationalist Movement in India, New York: Columbia University Press.

Kapur, Ratna (1999) 'Cultural Politics of Fire', Economic and Political Weekly, 34 (21), pp. 1297-9.

Latour, Bruno (2002) 'What is Iconoclash? Or Is There a World Beyond the Image Wars', in Peter Weibel \& Bruno Latour (eds.) Iconoclash: Beyond the Image-Wars in Science, Religion and Art, Cambridge: MIT Press, pp.14-37.

Lawrence, Bruce B.; Karim, Aisha (eds.) (2007) Violence: A Reader, Durham: Duke University Press.

Mahajan, Gurpreet; Reifeld, Helmut (eds.) (2003) The Public and the Private: Issues of Democratic Citizenship, New Delhi: Sage Publications.

Mahmood, Saba (2005) Politics of Piety: The Islamic Revival and the Feminist Subject, Princeton: Princeton University Press.

Rajagopal, Arvind (2001) Politics After Television: Hindu Nationalism and the Reshaping of the Public in India, Cambridge: Cambridge University Press.

Ramaswamy, Sumanthi (ed.) (2003) Beyond Appearances? Visual Practices and Ideologies in Modern India, New Delhi: Sage Publications.

Sen, Attreyee (2007) Shiv Sena Women: Violence and Communalism in a Bombay Slum, Indiana: Indiana University Press.

\section{NOTES}

1. In many instances of attacks on artists, the attackers came prepared with video cameras and even 'warned' news channels in advance. Most of the attacks occurred during working days, in public places and in the presence of onlookers and spectators.

2. On Sanskrit expressions related to 'house heroes', see the introduction to this issue.

3. See for example Hoskote (2004) and Kapur (1999). 
4. The following observations are based on my field research for an ongoing doctoral thesis on 'The rise of religious nationalism and freedom of expression of artists in India'. The fieldwork was carried out at various times between 2008 and 2010 primarily in New Delhi, Baroda, Ahmedabad, Mumbai and Jaipur, studying over 40 cases of violence against artists. The interviews of Niraj Jain, Afsar Khan and Diwakar Rawate were conducted, for most part, in Hindi. However, to lay emphasis on certain ideas Jain and Rawate used (often grammatically incorrect) English sentences and words, especially those related to women and sex. Despite their usage of certain English phrases, both Diwakar and Jain were adamant that I pose the questions in Hindi. Khan, on the other hand, did not use English at all.

5. All quoted sequences in this section, unless otherwise mentioned, are from the author's interview with Niraj Jain in Baroda (Gujarat) on 17 February 2008.

6. An ex-member of the VHP, a pro-Hindutva organization, Babu Bajrangi is one of the main accused of the 2002 Gujarat pogroms, involved in the killings of more than a hundred Muslims. $\mathrm{He}$ is presently on bail and runs an NGO, Navchetan Trust. Among its many activities, is 'rescuing', or forcibly separating, inter-caste couples, especially Hindu women married to Muslim men. See also Bunsha (2006).

7. Babu Bajrangi's involvement in the post-Godhra violence against Muslims was 'proven' and publicized through a 'sting operation' carried out by the news journal Tehelka in September 2007.

8. Jain narrated his family history and its conversion to Jainism, 'My father's grandfather was a diwan of a very big estate in Bharatpur. We are kshatriyas. Whatever happened in 1857 (...) the war of 1857 is mentioned in the history of that estate. A lot of things happened through his hands. Being the diwan he was fighting the war. So he was very worried and sad that he killed so many people. So a Jain sadhu (holy man) was passing by (...) but I believe Hinduism is our way of living life'.

9. Known for its erotic sculptures, Khajuraho here refers to a group of medieval Hindu and Jain temples built in the town of Khajuraho in Madhya Pradesh. For an understanding of the "new obsessive preoccupation with the site of Khajuraho' and its referrals to nudity in art, see GuhaThakurta (2004).

10. Diwakar Narayan Rawate, interview by author, Mumbai, 26 August 2008.

11. Founded by Bal Thackeray on June $19^{\text {th }} 1966$, the Shiv Sena is a regional, extremist political party from Maharashtra. Militant in its approach, the name translates as 'army of Maratha ruler Shivaji'. The tiger is its symbol. The early guiding motto of the movement was to favor rights of 'original' Marathis in the state over those of 'outsiders' who had settled in Mumbai for reasons of work, etc. From 1970 onwards, the party placed considerable importance on the Hindutva ideology, while continuing to canvass for its original cause in favor of Marathis. The Shiv Sena has since been at the helm of politics and social life, especially in Mumbai.

12. Throughout the interview Rawate respectfully addressed Thackeray as 'Bala Sahibji'.

13. For an in-depth study of Shiv Sena's organizational structure, working and violence, see Gupta (1980), Blom Hansen (2001) and Sen (2007).

14. Emphasis in the interview.

15. Based on the interview with the author, Hyderabad, 5 January 2010.

16. However, he showed an immediate generosity in his interaction after I told him that I was interested to know about 'his work'.

17. Emphasis mine.

18. Interviewed by the author, New Delhi, July 2010. 


\section{ABSTRACTS}

This article addresses the issue of violent, controversial attacks on artists and works of art in India, which have been increasing with the rise of religious nationalism since the 1990s. It argues that understanding the attacks solely on the basis of religious and political ideologies, though demonstrable, may not be adequate, for it overlooks the most important agent of action: the individuals who lead the attacks and indulge in violence. I argue that a common theme that defines the microsociological make-up of this violence is the choice for glory through a collective imagination, a personal take on the cult of the hero.

\section{INDEX}

Keywords: art, heroes, iconoclash, India, individual activism, religious nationalism, violence, women

\section{AUTHOR}

\section{MALVIKA MAHESHWARI}

Doctoral candidate, CERI-Sciences Po, Paris 